\title{
AN OVERVIEW OF FOREIGN RELATION OF NEPAL WITH CHINA
}

\author{
Girdhari Dahal \\ Department of Political Science, Prithvi Narayan Campus, Tribhuvan \\ University, Pokhara, Nepal \\ Email: gddahal1234@gmail.com
}

\begin{abstract}
Nepal and China have a long history of foreign relation since ancient time. As a modern state, Nepal established its diplomatic relations with China in 1955. The main objective of this paper is to explore the foreign relation of Nepal with China. This study uses secondary data for the collection of facts and information. It is descriptive and analytical in nature. This study is based on Constitution of Nepal, bilateral treaties, joint statements of high level official visits and different scholarly articles. Basic principles of the foreign policy of Nepal and China is set by mutual trust and the guidelines of Panchasheel. Nepal has always followed and accepted the One-China policy. Also, Nepal has supported the ambitious Chinese initiatives for one belt one road project. Similarly, China has been Nepal's key development partner. China has helped Nepal in different development projects. Nepal has signed a transit treaty with China. Now, Nepal has an alternative for third country transport transit.
\end{abstract}

Keywords: Bilateral relation, dialogue, diplomatic relation, negotiation, transit treaty

\section{Introduction}

Nepal is a beautiful landlocked country situated in South Asia. 
It has a very good relationship with its neighboring countries and other countries of the world. Nepal is located between China and India. These two countries are the emerging power of the world. India surrounds Nepal in the east, west, and the south and China borders in the north. Nepal and China officially established diplomatic relation in 1955. At present, Nepal and China enjoys friendly and cordial relation by respecting each other's sovereignty, territorial integrity and independence. The Chinese Embassy to Nepal (2007) has characterized Nepal-China relations as based on "trust, equality and sincerity". It further adds; the two countries never threat each other, harm each other or doubt each other; but always respect each other, believe each other and help each other. The Chinese Government and people firmly pursue the principle that a country is equal with others no matter how big or small it is. In the past 74 years, abiding by the Five Principles of Peaceful Coexistence, through equal dialogue, communication and coordination, China and Nepal have made excellent cooperation and achieved great accomplishments in bilateral political relations, regional affairs and international forum. China treats Nepal as its closest neighbor and as one of the best friends. In a report by the Chinese Embassy, it has stated that 'We highly appreciate the strong support Nepal has given to us over the years on the questions of Taiwan and Tibet and other major issues related to China's sovereign rights and interests'(Chinese Embassy to Nepal, 2015).

Nepal has always shown a strong commitment to 'One China Policy' and has never allowed its soil to be used for any hostile activities against China. China has also supported late king Birendra's proposal to declare Nepal as 'Peace Zone' and has never interfered with the internal affairs of Nepal and highly respected the road of development chosen by the Nepalese people (Chinese Embassy, 2007). China has always been a good 
partner in Nepal's development endeavor.

\section{Research Methodology}

The general objective of this paper is to explore Nepal and China relation. This paper makes a brief analysis of foreign relation of Nepal with China. This paper explores the various aspects of foreign relation of Nepal with China. This study is based on secondary data. Basically for this study, Constitution of Nepal 2015 is a major document as it is a guideline for Nepal's foreign relation with other countries. Different bilateral treaties, joint statements of high level official visits, website of foreign ministry of Nepal are used in this study. Similarly, books on foreign relation and journal papers are used for the study. This study focuses on historical relation, high-level visit of both countries and different areas of co-operation. This study is descriptive and analytical in nature.

\section{Review of Literature}

Constitutionally, foreign policy is to be guided by the directive principles. Safeguard of freedom, sovereignty, territorial integrity, independence, and foreign policy based on Panchasheel, United Nations Charter, non-alignment, international law and world peace are the general directive principles for Nepal's foreign policy (Constitution of Nepal, 2015). In practice, Nepal's foreign policy has not been directed towards projecting influence internationally but towards preserving autonomy and addressing domestic, economic and security issues.

Nepal's foreign relations in consonance with the policies and guidelines of the Government of Nepal are made to protect Nepal's independence, sovereignty, territorial integrity, and enhance national interest abroad; to promote bilateral, regional and multilateral relations for the socio-economic development of 
the country, to promote friendly relations with all the countries of the world and particularly with its immediate neighbors, on the basis of sovereign equality, mutual respect, trust, goodwill and understanding to play an active role in the United Nations and other international organizations, in order to promote international peace, security and development to play a positive and meaningful role in the world. (MOFA, 2017)

Nepal and its geographical proximity and historical links with China, Nepal's foreign policy was focused mainly on maintaining close and friendly relations with China in safeguarding its national security and independence (Savada, 1991). The successful second pro-democracy movement, the country needs to examine its conduct of foreign policy in the context of those changes and formulate and adopt its foreign policy correspondingly (Bhattarai, 2013).

Under the leadership of the Communist Party of China and the guidance of Marxism-Leninism and Mao Xedong Thought, the Chinese people of all nationalities will continue to adhere to the people's democratic dictatorship and follow the socialist road, steadily improve socialist institutions, develop socialist democracy, improve the socialist legal system and work hard and self-reliant to modernize industry, agriculture, national defense and science and technology step by step to turn China into a socialist country with a high level of culture and democracy. (The Constitution of People Republic China, 1982:7)

China adheres to an independent foreign policy as well as to the five principles of mutual respect for sovereignty and territorial integrity, mutual non-aggression, non-interference in each other's internal affairs, equality and mutual benefit, and peaceful coexistence in developing diplomatic relations and economic and cultural exchanges with other countries (The Constitution 
of People Republic China, 1982:7).

\section{Nepal-China Historical Relation}

Nepal and China share deep-rooted and age-old friendly relations with each other. According to Swayambhu Purana, the Kathmandu valley was a lake in the pre-history period. Bodhisattva Maha Manjushree came to the Kathmandu valley from Wu Tai-shan, China, and cut the gorge at Chobhar and drained out the water and human settlement was made possible in Kathamandu valley (Shrestha, 2016: 48). Buddhist monasteries first appeared in China during the Eastern Han dynasty but it was only after the Western Tsin dynasty (255-316) that Buddhism began to spread in China and flourished in the Southern Dynasty (Shrestha, 2016). Nepal and China relation exists since the $5^{\text {th }}$ century BC (Subedi, 2016). In the fifth century, famous Chinese Traveler Faxian returned to China after the visit to Ramgram, Kapilvastu, and Lumbini (Shrestha, 2016).The marriage of Nepalese Princess Bhrikuti Devi with the emperor of Tibet, SongtsanGampo in $7^{\text {th }}$ century (Chinese Buddhist Encyclopedia), visit of Nepali craftsman Araniko to China in the 13th century and visits to Nepal by Chinese monks and scholars at different periods in history paved a solid foundation in the development of Nepal-China relation (Bhandari, 2017).

\section{Rising Superpower of the world}

China is the emerging superpower of the world. With its military powers, China is also close to claiming a superpower status(Acharya, 2019:46). According to Acharya, explaining about China, China's President Xi Jinping has already indicated that China will be ready to lead the world (Acharya, 2019:46). He adds the global power of the united states and Europe is on the decline, while that of China and India is on the rise (Acharya, 
2019:46).According to prime minister KP Sharma Oli, "One would feel really proud of talking about Nepal China relationship. Nepal and China are close neighbors linked by geography, culture, and traditions. Both countries share a multidimensional relationship that encompasses political, economic, social, and cultural aspects (Oli, 2018).

Nepal is firmly committed to the one-China policy. We have a principled position that we do not allow our soil to be used against China. This is translated into day to day reality. Our two countries have been in close and continuous engagement in the fields of economy, trade and commerce, and culture and people to people relations. These two countries have a long history of trade relations that began with the engagement of merchants from either side of the Himalayas since the early days. The trade relationship has abundantly contributed to cementing the foundation of our economic relationship. Nepal and China have signed MoUs and agreements including Framework Agreement on Promotion of Investment and Economic Cooperation, MoU on Energy Cooperation and $\mathrm{MoU}$ on Investment and cooperation on Production Capacity. It will facilitate and reinforce the collaboration between the investors of the two countries. Nepal has joined the Belt and Road Initiatives (BRI), a visionary initiative launched by President Xi Jinping. We believe that this initiative offers immense opportunities for collaboration and partnership between our two countries. The growing attraction of the international community towards BRI has made it one of the biggest platforms for international cooperation. (Oli, 2018)

Belt and Road Initiatives (BRI) of China is one of the biggest projects in the world. Nepal already signed and agrees for it. This project has an ambition to connect China to Asia and Europe through road/rail networks. It is a highly significant and 
multidimensional project of the Republic of China. It is also expected to bring development opportunities and open trade and foreign investment activities in Nepal, too.

Nepal has to create space for its neighborhood policy based on the regional strategy of major blocks, powers, and neighbors around it. Traditionally, Nepal's foreign policy has been neighbourcentric (Acharya, 2019:273). Now Nepal has tried to keep a balanced relation with neighbour countries: China and India. Geographically it is close to India, but India has from time to time done economic blockade affecting the delivery of goods and services to the people.So, as an alternative, Nepal has done transit treaty with China. So it is an attempt towards balanced relation with both neighboring countries. Nepal must remain respectable and dignified maintaining mutually beneficial relations with its immediate neighbors China and India. China has a deep and close relation with Nepal. However, geographically access to China is more difficult than India. Now Chinese government has announced for Kerung -Rasuwa- Kathamandu Railway and Kathmandu-Pokhara-Lumbini Railway transport.

President Xi Jinping has envisioned the famous " Chinese Dream" which seeks to share China's prosperity to all the countries in the region (Acharya, 2016). China is a developing country and it has a great plan for the near future that will transform it into a developed country in the world. It has done a very fast industrial development and is making very high economic development to rise as a super power of the world. China has strong bilateral relations with five South Asian countries with which it has contiguous land borders with Afghanistan, Bhutan, India, Nepal and (Acharya, 2016).

\section{Major Cooperation Sector}

Nepal- China relations have always remained very friendly and 
based on mutual trust and unconditional cooperation. China is all the time, an important development partner of Nepal. It has assisted various sectors: social, economic, cultural, science and technology, investment, energy, trade and invest, agricultural, tourism and human resource with more than 31 projects during the past 60 years (Kusum, 2016: 38). So many Highway, road, transportation project, paper mills, Saja Bus etc. The Chinese Ambassador to Nepal Wu Chuntaistates that China's new leadership has accorded high priority to relations with Nepal and sought a win-win policy with Nepal (Shrestha, 2016:97).

Nepal foreign policy has been its policy towards its neighbors. China is the most significant source of Foreign Direct Investment (FDI), tourists, trade and aid in Nepal (Acharya, 2016). Nepal economic diplomacy has been done for the various foreign aid and investment for the development of infrastructure. It has tried to economic development through the political established the people of Nepal mandate almost 2/3 majority to the Communist Party of Nepal (CPN). Its aims are prosperous and happy Nepali through economic development. Its needs more investment in foreign aid for overall development (Oli, 2017). China is the development partner of Nepal. It has always wanted to progress and prosperous of Nepal because of Chinese argument for the overall development of Nepal.

\section{Result and Discussion}

Nepal and China relation are friendly, bilateral and cordial. Both have respected each other as a good neighbor. It has friendly relation since the time of Araniko and Bhirkuti. These relations have been marked by friendliness, mutual support and understanding and appreciation of each other's aspirations and sensitivities. Both the countries are abiding by the ideals of the Five Principles of Panchasheel. China is one of the major 
donor countries of Nepal. Nepal and China first signed an agreement on economic aid in 1956. The Chinese Government has provided grant assistance to the Government of Nepal under the Economic and Technical cooperation in order to implement mutually acceptable development projects (MOFA). Before that also there was various sector cooperations between them. China has been providing financial and technical assistance to Nepal in the areas of infrastructure development, transportation, industrial development, health, education, hydropower development, etc. Some of the major projects built under Chinese assistance are: Arniko Highway $(115 \mathrm{~km})$ from Kodari to Kathmandu, it is northeast of Kathmandu Valley, on the Nepal China border. At the Sino- Nepal Friendship Bridge it connects China National Highway 318 to Lhasa, and finally to Shanghai. It was made in 1960.

Similarly, China has built Prithvi Highway (174KM) from Naubise to Pokhara. This highway establishes a connection between Kathmandu and western Nepal. It was made in 1967, it connect capital city of Kathmandu to tourist city Pokhara. Kathmandu Ring Road (27 KM) was made 20 years ago and extends to 8 lanes recently. Pokhara-Baglung highway connects Kaski, Parbat and Baglung districts. Syaphrubesi Rasuwagadhi Road Project, thus highway and road transportation project support by China.

Bansbari Leather and Shoes Factory, Hetauda Cotton Textile Mills, Harisidhi Brick Factory, Bhrikuti Paper Mills, Lumbini Sugar Mills, Sunkoshi Hydroelectricity Plant, Pokhara Water Conservancy and Irrigation Project (Multipurpose), B.P. Koirala Memorial Cancer Hospital, Civil Service Hospital, National Ayurveda Research Centre, Satdobato Sports Complex, City Hall in Kathmandu and Birendra International Convention 
Centre (MOF, 2014) are all built by the aid from China. Also, the ongoing projects under Chinese assistance include Upper Trishuli Hydropower Project, Kathmandu Ring Road Improvement Project, Pokhara International Regional Airport, and National Armed Police Force Academy Project (MOF, 2014). With the signing of the Memorandum of Understanding on Cooperation under the one Belt and One Road Initiative on 12 May 2017 in Kathmandu between Nepal and China, new avenues for bilateral cooperation in the mutually agreed areas are expected to open (MOFA, 2017).

The foreign policy of Nepal is guided by the theory of Pahcheel and Constitution of Nepal. China's independent foreign policy guided according to the constitution of people republic China has set a foundation for its foreign relations. Both nations have mutual respect for each other's territorial integrity and sovereignty, mutual non-aggression, mutual non-interference, equality and mutual benefit, and peaceful co-existence. China is a close neighbour of Nepal, and it can have a significant impact on political stability as well as economic development. It provides various development activities for the good performance of Nepal.

\section{Current Development in Relation}

One of the landmarks in Nepal-China relation was built when the then Prime Minister K.P. Oli signed Transit and Transport Agreement in his official visit to China in 2016. At present, Nepal and China are enjoying very friendly, broader, and deeper relation followed by frequent exchange of high-level officials' visit from both sides. Nepal and China have new tangent treaties for an alternative point of view as well as one belt and one road initiative. In recent years, the leaders of India and China have focused on the development and economic prosperity. They have 
made significant advancement in the road, railway, and nautical connectivity. Xi Jinping's ambitious project of one belt one road has the aim to be connected with about 60 countries of Asia, Africa, and Europe. President Xi Jinping has a vision of creating a 'community of common destiny' through 'Go West' and 'Peripheral Strategy'(Subedi, 2016) Nepal has also supported and agreed with this ambitious one belt one road project.

\section{High-level visits}

Nepal and China have agreed and strengthened bilateral relations for mutual benefit, including through the regular exchange of high-level visits. At the invitation ofH.E. Mr. Xi Jinping, President of the People's Republic of China, Rt. Honorable President Mrs. Bidya Devi Bhandari was on the first leg of State Visit to the People's Republic of China on May 2019. During her first state visit to China, seven agreements were signed between Nepal and China in the presence of President Bhandari and President Xi Jinping. Both Presidents had bilateral talks, President Bhandari and President $\mathrm{Xi}$, witnessed the signing of a total of 7 bilateral agreements between the two countries. The state visit of Nepalese President Bidhya Devi Bhandari to China, which coincided with the Second Belt and Road Forum for International Cooperation held in Beijing, offered the two countries the opportunity to discuss mutual interests and exchange views at the highest political level (Subedi, 2019). President Ram Baran Yadav also had visited China twice (Adhikari, 2016:27). Similarly, last year vice president Nandabahadur Pun visited China. Also, late king Mahendra, Birendra, and ex-King Gyanendra visited China during their times.

Prime minister KP Sharma Oli, at the invitation of Chairman of the Tibet Autonomous Region (TAR) Mr. Qi Zhala, visited China together with Speaker of House of Representatives 
Mr.Krishna Bahadur Mahara, from 7-12 September 2018 leading a delegation. Ex-prime minister Puspakamal Dahal also visited China for cordial relation between both the countries. Sher Badahur Deuba and Manmohan Adhikari, Tanka Prasad Acharya, BP Koirala as the head of government had been on a visit to China in time to time for friendship and to develop people to people relation.

\section{Conclusion}

Nepal and China are the closest neighbors. Nepal always follows the Pancheelsheel theory, non-alignmovement, and world peace. Both are peace lover countries. Both countries have cordial relation since the ancient period to the present. NepalChina relation has long history, although modern diplomatic relation was developed only 69 years ago. Nepal and China relation started before Manjushree's visit who cut the gorge at Chobhar and drained out the water. Recently high-level visit of the head of the state and head of the government and ministry level and foreign secretary and the other official visit and unofficial people's visit as a tourist from both countries. Nepal and China relation was manifested in the form of various areas of cooperation for a deep cordial relationship.

\section{Reference}

Achayra, Madhu Raman (2019). Nepal world view, Volume I: Foreign Policy and Volume II: Diplomacy, Kathmandu: Adroit Publishers.

Adhikari, Chandra Shekhar (2016). Relations reflections on Nepal-China, Celebrating Nepal-China $60^{\text {th }}$ Year of Diplomatic Relations, Nepal: Institution of Foreign Affairs IFA.

Bhattari, Rajan (2005). Geopolitical specialties of Nepal and 
international approach to conflict transformation, Nepal: Friends for Peace in Jan 2005. https://indiamadhesi.files. wordpress.com/2008/10/geopolitics-of-nepal.pdf

Bhattarai, Rajan (2013). Foreign Policy in Nepal, Kathmandu: Martin Chautari, http://nepalpolicynet.com/images/ stories/happenings/130526_Invitation_Policy\%20 Discussion Copy.pdf

Chinese Buddhist Encyclopedia.

Chinese Embassy to Nepal (2015). http://np.china-embassy.org/ eng/ChinaNepal/t362330.htm

Chinese Embassy to Nepal (2007). http://www.chinadaily.com. $\mathrm{cn} / \mathrm{a} / 201905 / 13 / \mathrm{WS} 5 \mathrm{~cd} 8 \mathrm{~b} 57 \mathrm{aa3104842260bb2f5.html}$

Constitution of Nepal (2015). Kathmandu: Ministry of Parliamentary and Law ministry, Kanun Kitab Byabastha Committee.

Dahal, G. (2015). Constitutional Assembly of Nepal Milestone for Peace, Development and Political Stability: KMC Journal of Interdisciplinary Studies, 4(1), 70-77.

Dahal, G. (2018). Foreign Relation of Nepal with China and India. Journal of Political Science, 18, 46-61. https://doi. org/10.3126/jps.v18i0.20439

Embassy of Nepal (2015). http://www.nepalembassy.org/ guiding-principles/

Embassy ofNepalWashingtonDC,http:/www.nepalembassyusa. org/guiding-principles/

Government of Nepal Ministry of Foreign Affairs MOFA http:// mofa.gov.np/foreign-policy/foreign-policy/- 60 -

Government of Nepal Ministry of Foreign Affairs MOFAhttp:// mofa.gov.np/foreign-policy/diplomatic-relations/ 
http://www.mea.gov.in/Portal/ForeignRelation/8_Nepal_ November_2017.pdf

http://www.mea.gov.in/Uploads/PublicationDocs/191_ panchsheel.pdf

https://archive.org/stream/nepalbhutancountsava/ nepalbhutancountsava_djvu.txt

https://www.indianembassy.org.np/pdf

https://www.mea.gov.in/Images/pdf

https://www.mea.gov.in/Portal/ForeignRelation/Nepal_ July_2014_.pdf

https://www.mea.gov.in/Portal/ForeignRelation/Nepal_ July_2014_.pdf

https://www.India-foreign-relation-2012.pdf

Indian Embassy to Nepal (2015). http://np.india-embassy.org.

Kusum, Govind P. (2016). Nepal China Relations-Journey for a New Height, Celebrating Nepal-China $60^{\text {th }}$ Year of Diplomatic Relations, Nepal: Institution of Foreign Affairs IFA.

Oli, KP (2018). My Vision Prosperous Nepal Happy Nepali, Nepal: Office of Prime Minister.

Bhandari, Bibek (2017). China's Cultural debt to Nepalese artist in the 13th-century court of Kubal Khan. http:// www.scmp.com/magazines/post-magazine/long-reads/ article/2122813/chinas-cultural-debt-nepalese-artist13th-century

Shivakoti, Gopal (2013). Dictionary of Politics Nepali-EnglishNepali, Kathamandu: Pairavi Prakashan.

Shrestha, Hiranyalal (2016), History of Nepal-China Relations: 
Way forward,Celebrating Nepal-China $60^{\text {th }}$ Year of Diplomatic Relations, Nepal: Institution of Foreign Affairs IFA.

Shrestha, Rajendra B. (2016). Enhancing economic cooperation between China and Nepal, Celebrating Nepal-China $60^{\text {th }}$ Year of Diplomatic Relations, Nepal: Institution of Foreign Affairs IFA.

Shrestha, Rajendra B. (2018, 1 January). Foreign Policy Challenges and Opportunities, Kathmandu: The Rising Nepal.

Subedi, Mahedra (2019). China daily, Nepal president's visit to China opens up new vistas

Subedi, Suryaprasad (2016). Kathmandu Post, Kantipur Publication.

The Constitution of People's Republic of China (1982). China: Foreign Language Press.

The Kathmandu Post (2017, 4 March). Kathamandu, Kantipur Publication.

The Kathmandu Post (2016, 6 July). Kathamandu, Kantipur Publication.

Xinhuanet (2018). Chinese tourists flock to Nepal during Chinese New Year http://www.xinhuanet.com/english/201802/18/c_136983861.htm. 